https://doi.org/10.18485/kud_kiaz.2019.ch35

\author{
Афет Мусаева \\ Доктор философских наук по филологии \\ Азербайджанский Университет Языков \\ afetmusayeva20132@gmail.com
}

\title{
ВЛИЯНИЕ СУФИЗМА И ХУРУФИЗМА НА АЗЕРБАЙДЖАНСКУЮ ТВОРЧЕСКУЮ МЫСЛЬ
}

\section{SUMMARY}

Azerbaijan is a country that is geographically located at the intersection of East and West. The geographical position of our country, of course, influenced cultural diversity. In the cultural heritage of Azerbaijan you can see the strong influence of Sufism and hurufism. Sufism, and then one of its branches, Hurufism, representing a philosophical-religious trend, played a large role in the subsequent development of cultural thought in our country.

Key words: Sufism, hurufism, mysticism, religion.

Люди всегда увлекались мистикой, мистицизмом. И это неспроста. Слово мистика произошло от греческого слова «таинственный», и обозначало философское и богословское учение. Суть мистицизма состоит в любви к Абсолюту, к Истине (Богу). Мистицизм являет собой духовное начало человека. Ведь если цель научного познания заключается в изучении мира вокруг человека, то духовность - это наш внутренний мир. В наше время, когда на право духовного наставничества претендуют различные религии, слово «суфизм» до сих пор окутано тайной. На протяжении тысячи лет сущность суфизма пытались 
постичь ученые Ближнего и Среднего Востока, а затем и ученые всего мира. Но до сих пор постижение этой волнующей тайны будоражит умы многих исследователей.

Кто были первые суфии не знает никто. При зарождении ислама, мусульмане-аскеты, которые были одеты в шерстяные туники (sufarab), стали известны как суфии. Но понятие «суфизм», с его мистикой и символизмом достиг своей зрелости в 9-11х веках. Появление суфизма можно уподобить огромному старому дубу, стоящиму посреди поляны. Никто не знает как это дерево появилось, и кто его посадил. Но сейчас это дерево радует всех своей красотой, величием и силой.

Кто же такие суфии? Первая мысль, приходящая нам на ум - это бедный странник, в белом одеянии, способный медитировать. В реальности же, суфизм можно сравнить лишь с океаном, в котором очень много волн и крушений и добраться до неизведанной земли способны единицы, хотя начинают это путешествие многие. Человек, который решил следовать идеям суфизма, должен быть чрезвычайно смелым, так как цель очень далека и неизвестна. Но достижение цели оправдывает все трудности и лишения - конечный пункт - это постижение Истины, или другими словами Бога. Именно Бог является самой заветной целью, которую должен постичь странник. В этом долгом путешествии не может быть ошибок, потому что бездонный океан их не прощает и поглощает странника.

Исторически суфизм связан с исламом. Без ислама не могло бы появится и суфизма, который является духовным началом или мистицизмом в данной религии. Благодаря Мухаммеду и его сподвижникам единобожие стало распространятся на Востоке. Ислам стал мостом между христианским западным миром, впитавшим элинизм, и мирами Будды, Лао-Цзы, откуда было заимствовано понятие «Путь», а также медитация.

Суфизм можно назвать мистическим измерением ислама, основанном на глубинном значении Корана. Центральная доктрина суфизма основана на стихе из Корана: 
Я создал человека и вдохнул в него дух Мой.

Последователи суфизма считают, что эта «божественная искра», помещенная в каждого человека, должна быть воспитана и взлелеяна. Как было отмечено выше, главной целью суфи, является постижение Бога (Истины), но достигается это благодаря внутреннему свету и созерцанию, самоочищению и медитацией. Приближение к Богу может быть очень опасно, ведь чем ближе вы к Нему подходите, тем больше вы расстворяетесь в нем. Это самоубийсво, но настолько прекрасное, что для них оно становится настоящим блаженством. Слова одного из величайших суфи в полной мере раскрывают постижение Истины:

Костер горит, сжигая сам себя, ведь он Любовью истинною, божеской пленен... Любое сущее, что сжечь себя стремится, С Первопричиною своей соединится...

По словам Руми, другого великого суфи, человек, служа Богу, постепенно приближается к бежественному человеческому архетипу совершенного человека, который является центром Вселенной. Но для того чтобы стать совершенным человеком, нужно уничтожить себя, а затем заново возродится, и открыть в себе дар отказа от всего плотского существования:

По длинной и крутой тропе ты тащишь свой мешок. Ты утомился - посиди, передохни чуток. Да не забудь, пока сидишь, в мешок свой заглянуть: Что там такого набралось за этот долгий путь? Коль есть там стоящее что, тогда трудись, неси, А нет, так вытряхни его, не трать напрасно сил! Бери в мешок свой только то, что под конец пути, Не будет стыдно и смешно владыке поднести.

Одним из главных постулатов суфизма является Любовь к Всевышнему. Руми часто указывает на любовь как мотив Бога для создания мира. Бог создал мир любя, поэтому любовь порождает многообразие, которое заполняет всю вселенную. Он никогда не перестает любить свои создания, поэтому постоянно создает что-то новое. Все вокруг заполнено Любовью: 
Я долго искал Бога у христиан, но Его не было на кресте. Я побывал в индуистском храме и древнем буддийском монастыре, Но и там не нашел я даже следов Его. Я отправился к Каабе, но Бога не было и там. Тогда я заглянул в свое сердце. И только там узрел Бога, Которого не было больше нигде...

Почему странник-суфи терпит все тяготы, втречающиеся у него на пути добровольно? Почему любая горечь кажется ему сладостной? Он проходит через пустынные долины, высочайшие горы, попадает в страшные шторма, но не боится ничего. И почему он с таким нескончаемым воодушевлением направляется к своему конечному месту? Потому что он истинный верующий. Последняя и конечная цель суфи - это встреча с Истиной, и ничто в мире не может его остановить.

В эпоху раннего средневековья, будучи одним из самых значимых философско -литературных течений на Ближнем Востоке, суфизм распространился по всему исламскому миру, и конечно в Иране, а следовательно и на территории современного Азербайджана. Исследуя суфизм и анализируя творчество поэтов-суфи, невозможно не упомянуть, Низами, творчесво которого, с одной стороны впитало героическую поэзию великого иранского поэта Фирдоуси, а с другой стороны отражало в себе мистическую сущность суфийской поэзии Руми, Аттара и других поэтов-суфи. Низами смог объеденить в своем творчестве романтические аспекты человеческих отношений с героическими. Поэзия поэта пропитана глубокой духовностью и погружает читателя в сложный мир человеческой души. Низами был поэтом - мистиком, и в его творчестве ярко прослеживается символизм, связанный с древней персидской доисламской культурой.

Для Низами поэзия имеет почти божественный статус, во многих своих произведениях он сравнивает поэзию с самим Кораном, как источником ясного морального руководства. В «Сокровишнице тайны» он пишет: 
Первым проявлением человеческой сущности была речь...

Без речи в мире нет голоса.

Читая произведения Низами, так же как и других поэтов - суфи, читатель сталкивается с несколькими уровнями понимания произведения: на поверхностном уровне, мы воспринимаем его произведения как любовную лирику, но эти стихи имеют намного более глубокий смысл, в них поэт описывает тернистый Путь к постоянному поиску Истины:

Тропы мне ни в духан, ни к богу нету. И тут и там покорен я запрету: В мечеть пойти - пристало ли гуляке? В кумирню - презираю чашу эту. А все же есть, меж храмом и кумирней, Один лишь путь. Его открыть бы свету!

В восхитительной истории о Фархаде и Ширин, пересказанной Низами, ярко проиллюстрирован тяжелый путь, и в конце концов постижение Истины. Однажды Фархад спросил у Ширин,что ему сделать, чтобы она согласилась на встречу с ним? Она улыбнулась и сказала: «Если ты сможешь прорыть арык в скале одной киркой, тогда сможешь прикоснуться ко мне.» Много времени потратил Фархад на этот тяжелый труд, но в конце концов, он достиг Ширин. Все печали, горести, трудности, катаклизмы забываются, когда встречаешься с Бесконечностью.

В 14-15-х веках, появилось новое религиозно-философское течение хуруфизм, которое получило большое распространение на территории нынешнего Азербайджана. Основателем хуруфизма следует считать Тебризского мыслителя Ф. Наими. Хуруфизм являет собой наполовину религиозное, и наполовину философское течение, опирающееся на основы пантеизма. Основным постулатом пантеизма стала идея о том, что Бог существет не отдельно от человека и природы, а воплощен во всех своих созданиях. Главным каноном хуруфитов было то, что Создатель и его создания едины. Они верили в особую систему, образу- 
ющую действительность: Бог, Слово, Вселенная, Человек. Ф.Наими в своем творчестве постоянно развивал эту идею, и окончательно оформил ее в «Джавиднаме»:

Идеальный человек - величественее солнца, луны и звезд.

Хуруфизм также как и суфизм являлся мистическим философским-религиозным течением, поэтому символы в творчестве художников слова играли огромную роль. Так например, они считали ,что Бог отражен в двух ипостасях: в форме слова и в форме человека. В «Джавиднаме» и в других произведениях Наими говорится, что слово является абстрактным выражением реальной действительности. Таким образом, Коран является Истиной в словах:

Без слова невозможно признать само существование

Слово мое, Коран мой, книга моя, мысли мои, Намаз мой, поклон мой, нежность моя, дар мой.

Одним из самых ярких представителей хуруфизма и последователем Ф.Наими стал И.Насими. Насими провел детство и юность в городе Шемахе, получил хорошее образование и принял идеи хуруфизма, считая Ф.Наими своим идейным наставником. И.Насими является одним их первых поэтов, создателей литературного азербайджанского языка. Представители хуруфизма прошли тяжелый и тернистый путь, некоторые из них поплатились своими жизнями за приверженность своим идеям. Такая участь сложилась у Наими, а затем и Насими. Насими был великим гуманистом, наделяющим человека богоподобными качествами.

В меня вместятся оба мира, но в этот мир я не вмещусь. Я - суть, я не имею места, и в бытие я не вмещусь. Всё то, что было, есть и будет-всё воплощается во мне. Не спрашивай. Иди за мною. Я в объяснения не вмещусь.

Поэт считал, что познание Истины (Бога) начинается с постижения человеческой сущности, и не исследовав внутренний мир человека невозможно постичь Бога. Хуруфиты воспринимали две формы поклонения Богу: 
сердцем и глазами. Они уподобляли красивое лицо Каабе. По признанию Насими, Любовь - наивысшее чувство, и постичь истину возможно только испытав любовь:

Луноликая пери, шалунья, восторг, озорница, Мой жасмин, кипарис, моя роза, изящества чадо, Совершенство, избранница, чудо любви, диво страсти, Ты - кумир мой, Кааба, ты - гурия райского сада.

Одной из важнейших идей в учении хуруфизма была мысль о разделении людей на две категории: с одной стороны, мудрые люди, постигшие истину, или стремящиееся ее постичь; с другой стороны - невежественные люди. Хуруфиты определяли невежественного человека, как корыстного, связанного с материальным миром, и называли это -худшим злом. Насими писал:

Кто освободится от корысти своей,

Тот окрылен будет подобно птице.

Насими казнили, так как его творчество носило бунтарский характер, его идеи были прогрессивными и воспевали величие разума и были направлены на освобождение личности от условностей и застывших устаревших догм. Именно поэтому творчество этого великого азербайджанского поэта оказало огромое влияние на творчество всех последующих прогрессивных мыслителей Азербайджана, таких как Гусейн Джавид, Микаил Мушвиг, Ахмад Джавад и многих других. Жизнь и творчество поэта многие века является примером несгибания и самопожертвоания ради своих идей. Насими был личностью с несгибаемой волей, человеком который пошел на казнь за свои убеждения, не изменяя им до последнего дыхания.

Чтоб этот мир понять, им восхититься надо, Чтоб свет любви познать, страдать в темнице надо, И, если ты султан, а хочешь видеть бога, С престолом и венцом тебе проститься надо. 


\section{Использованная литература:}

Jamal J. Elias. Iranian Studies.Vol. 31, No. 3/4, A Review of the "Encyclopaedia Iranica" (Summer - Autumn, 1998), pp. 595-613

Nizami Gəncəvi.Xosrov və Şirin.- Bakı. Çaşığlu,2004.

«Азербайджан», №8, 1973.

Азероглу Б. Наими и Насими//Азербайджан, №8, 1973.

Бабаев Я. М. Хуруфизм и его влияние на азербайджанскую литературу // Молодой ученый.2009. №3. С. 100-104

Лео Яковлев. Суфии. Восхождение к истине // Москва ЭКСMO. 2003 c. $96-100$

\section{PЕЗЮME}

Азербайджан - это страна, которая с географической точки зрения находится на пересечении Востока и Запада. Геграфическое положение нашей страны, конечно же, повляло на культурное многообразие. В культурном наследиии Азербайджна можно увидеть сильное влияние суфизма и хуруфизма. Суфизм, а затем одно из его ветвей хуруфизм, представляя собой философско-религиозное течение, сыграли большую роль на все последующее развитие культурной мысли нашей страны.

Ключевые слова: суфизм, хуруфизм, мистицизм, религия. 